\title{
Operation of the Uncultivated Land Tribunal for Finnmark has ceased due to lack of funds
}

The Uncultivated Land Tribunal for Finnmark is a special court constituted under the 2005 Finnmark Act with a mandate to arbitrate in rights disputes arising from Finnmark Commission investigations of land tracts. The tribunal, like the Finnmark Commission, is a body established under the Finnmark Act's legal clarification process to accomplish Norway's obligations to the Indigenous Sámi under international law. In particular, in relation to the ILO Convention No. 169 concerning Indigenous and Tribal Peoples in Independent Countries' obligation to "take steps as necessary to identify the lands which the peoples Concerned traditionally occupy," and to establish "adequate procedures ... within at the national legal system to resolve land claims by the peoples Concerned."

The Uncultivated Land Tribunal for Finnmark has been operative since September 2014 and has recently issued its first judgment, which concerns a Sámi reindeer herder group's claim of ownership to land on Stjernøya in West Finnmark directed at Finnmarkseiendommen (the Finnmark Estate) as land owner. The Sámi did not succeed with their claim and consequently lost the case. However, the land tribunal elaborated on some interesting interpretations of law in the well-reasoned judgment. In contradiction to arguments made by the Finnmark Estate, the tribunal emphasized that the ILO Convention No. 169 is incorporated into Norwegian law and is applicable within the sphere of the Finnmark Act. Furthermore, the tribunal also ruled against the Finnmark Estate arguments when it found that predominant use of an area in question by Indigenous Peoples is sufficient to establish property rights according to the ILO Convention No. 169. Consequently, exclusive use is not required.

The first working year of the tribunal was characterized by the majority of cases being dismissed or withdrawn, rather than being perused for judgment. This can perhaps be explained by the tribunal's narrow interpretation of its mandate, as it has assumed that the tribunal shall not hear claims that have not first been heard by the Finnmark Commission.

However, this first working year of the tribunal will now be remembered largely for how it ended - the tribunal has suspended its operations because of lack of budgetary funding. This has affected an important collective use rights case brought by Nesseby bygdelag (an association for residents of part of Nesseby) in the Sámi 
Municipality of Nesseby in East Finnmark that was scheduled for September 2015 and has now been postponed until 2016. In its reasoning for suspending its activities, the tribunal highlighted the demands and the financial strain of covering parties' expenses associated with legal proceedings in Alta in June 2015.

The suspension of the tribunal's operations has attracted attention beyond the borders of the Finnmark county. In the concluding observations on Norway (CERD/ $\mathrm{C} / \mathrm{NOR} / \mathrm{CO} / 21-22)$, the Committee on the Elimination of Racial Discrimination (CERD) leveled harsh criticism against Norway, partly because there remain significant gaps in translating the legal recognition of the Sámi rights of land and resources into practice, thus, in reality, resulting in limited recognition and protection of rights over their lands. Particularly, in section 29 (c) of the observation document, the committee addresses "the fact that the funds used to provide legal aid to those seeking recourse to the Uncultivated Land Tribunal for Finnmark come out of the budget of the Tribunal, thus restraining the work of the Tribunal."

Oyvind Ravna Editor-in-chief 